\title{
NUEVAS OBSERVACIONES EN LA ALIMENTACIÓN DE LAS AVES
}

\author{
De la Peña, M. R. ${ }^{1}$
}

\begin{abstract}
RESUMEN
Se describen los resultados de las observaciones sobre la alimentación de 36 especies de aves. Las mismas se realizaron en forma directa, identificándose las ingestas de la dieta. En cada caso se registra la fecha y el lugar. Para algunas especies se indica si los alimentos eran llevados a los pichones.

Palabras clave: alimentación, aves, Argentina.
\end{abstract}

\section{SUMMARY}

\section{News observations on bird feeding}

The results of observations of feeding habit of 36 birds species are described. These were conducted directly, identifying intake quality. In every case, date and location were recorded.

In some species, is indicated if seed is taken to the nestlings.

Key words: feeding, birds, Argentina.

1.- Martín Rodolfo de la Peña. Médico Veterinario. Académico Correspondiente de la Academia de Agronomía y Veterinaria. 3 de Febrero 1870. (3080) Esperanza, provincia de Santa Fe.

E-mail: martin@fca.unl.edu.ar

Manuscrito recibido el 22 de febrero de 2002 y aceptado para su publicación el 27 de noviembre de 2002. 